\title{
Determinan Balita Stunting di Jawa Timur: Analisis Data Pemantauan Status Gizi 2017
}

\section{Determinants of Stunted Toddler in East Java: Analysis of the 2017 Nutrition Status Monitoring Data}

\author{
Agung Dwi Laksono ${ }^{1}$,Hario Megatsari ${ }^{2 *}$
}

\begin{abstract}
ABSTRAK
Latar Belakang: Stunting dalam kehidupan awal akan mempunyai konsekuensi fungsional yang merugikan, termasuk kognisi yang buruk dan tingkat pendidikan yang rendah. Variabel ini perlu diperhatikan karena menurut Unicef, ada faktor sosial budaya yang berperan dalam terjadinya permasalahan stunting. Penelitian ditujukan untuk menentukan determinan balita stunting di Jawa Timur.

Metode: Penelitian menggunakan data sekunder survei Pemantauan Status Gizi tahun 2017 (PSG 2017). Dengan metode multistage cluster random sampling, diambil sampel 10.814 balita berusia 0-59 bulan. Varibel yang dianalisis terdiri dari variabel dependen status gizi balita, 7 variabel independen: tempat tinggal, umur balita, umur ibu balita, status perkawinan ibu balita, tingkat pendidikan ibu balita, dan status bekerja ibu balita. Penentuan determinan dengan menggunakan uji Regresi Logistik Biner.

Hasil: Balita yang tinggal di daerah perkotaan 0,855 kali lebih memiliki risiko stunting dibandingkan dengan balita yang tinggal di daerah pedesaan (OR 0,885; $95 \% \mathrm{Cl} 0,798-0,980$ ). Balita yang memiliki ibu dengan pendidikan SD ke bawah 2,206 kali lebih memiliki risiko stunting dibandingkan dengan balita yang memiliki ibu dengan pendidikan perguruan tinggi (OR 2,206; 95\% $\mathrm{Cl}$ 1,835-12,651). Balita yang memiliki ibu dengan pendidikan SLTP 1,676 kali lebih memiliki risiko stunting dibandingkan dengan balita yang memiliki ibu dengan pendidikan perguruan tinggi (OR 1,676; 95\% Cl 1,395-2,015). balita yang memiliki ibu dengan pendidikan SLTA 1,266 kali lebih memiliki risiko stunting dibandingkan dengan balita yang memiliki ibu dengan pendidikan perguruan tinggi (OR 1,266; 95\% Cl 1,058-1,514).

Kesimpulan: Ada 4 variabel yang terbukti signifikan sebagai determinan kejadian stunting di Provinsi Jawa Timur, yaitu tempat tinggal, umur balita, umur ibu balita, dan tingkat pendidikan ibu balita.

Kata Kunci: stunting, determinan, status gizi, gizi masyarakat
\end{abstract}

\section{ABSTRACT}

Background: Stunting in early life will have adverse functional consequences, including poor cognition and low levels of education. The study aimed to determine the determinants of stunting toddlers in East Java.

Methods: The study uses secondary data from the 2017 PSG. Using the multi-stage cluster random sampling method, a sample of 10,814 toddlers aged 0-59 months was taken. The analyzed variables consisted of the dependent variable nutritional status of toddlers, 7 independent variables: residence, toddler age, mother's age, marital status of mothers, mother's education level, and working status of mothers. Determination of determinants using the Binary Logistic Regression test.

Results: Toddlers living in urban areas were 0.855 times more at risk of stunting compared to toddlers living in rural areas (OR 0.885; 95\% Cl 0.798-0.980). Toddlers who have mothers with elementary education and below 2.206 times have more risk of stunting compared to toddlers who have mothers with college education (OR 2.206; 95\% Cl 1,835-12,651). Toddlers who have mothers with junior high school education were 1,676 times more likely to have stunting risk compared to toddlers who have mothers with tertiary education (OR 1.676; 95\% Cl 1.395-2.015). toddlers who have mothers with high school education are 1,266 times more likely to have stunting risk compared to toddlers who have mothers with tertiary education (OR 1,266; 95\% CI 1,058-1,514).

Conclusion: There were 4 variables that have proven to be significant as determinants of stunting in East Java Province, namely residence, age of toddler, age of toddler mother, and mother's level of education

Keyword: stunting, determinant, nutritional status, community nutrition

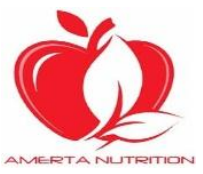

(C)2020. Laksono dan Megatsari. Open access under CC BY - SA license.

Received: 23-12-2019, Accepted: 10-02-2020, Published online: 18-06-2020.

doi: 10.20473/amnt. v4i2.2020.109-115 . Joinly Published by IAGIKMI \& Universitas Airlangga 


\author{
*Koresponden: \\ Hario Megatsari \\ hario.megatsari@fkm.unair.ac.id \\ ${ }^{2}$ Departemen Promosi Kesehatan dan IImu Perilaku, Fakultas Kesehatan Masyarakat, Universitas Airlangga Surabaya \\ ${ }^{1}$ Puslitbang Humaniora dan Manajemen Kesehatan, Kementerian Kesehatan RI. Jl. Percetakan Negara 29, Jakarta, Indonesia.
}

\section{PENDAHULUAN}

Secara definisi, stunting (kerdil) adalah kondisi dimana balita memiliki panjang atau tinggi badan yang kurang jika dibandingkan dengan umur. Kondisi ini diukur dengan panjang atau tinggi badan yang lebih dari minus dua standar deviasi median standar pertumbuhan anak dari WHO ${ }^{1}$. Stunting pada masa anak-anak adalah indikator yang terbaik untuk mengukur kesejahteraan anak-anak dan merefleksikan secara akurat dari situasi kesenjangan social yang ada ${ }^{2}$. Balita stunting termasuk masalah gizi kronik yang disebabkan oleh banyak faktor seperti kondisi sosial ekonomi, gizi ibu saat hamil, kesakitan pada bayi, dan kurangnya asupan gizi pada bayi. Balita stunting di masa yang akan datang akan mengalami kesulitan dalam mencapai perkembangan fisik dan kognitif yang optimal ${ }^{1}$. Kejadian stunting pada anak juga memiliki konsekuensi kesehatan jangka panjang. Bukti menunjukkan bahwa stunting dalam kehidupan awal akan mempunyai konsekuensi fungsional yang merugikan, termasuk kognisi yang buruk dan tingkat pendidikan yang rendah, kelak pada saat dewasa memiliki gaji yang rendah, kehilangan produktivitas dan, jika disertai dengan kenaikan berat badan di masa kanak-kanak, akan meningkatkan risiko penyakit kronis yang berhubungan dengan gizi ${ }^{3}$.

Berdasarkan data dari Bappenas, selama 20182019 Provinsi Jawa Timur merupakan salah satu provinsi yang menjadi wilayah prioritas penangan permasalahan stunting. Pada tahun 2018, Jawa Timur memiliki 11 lokus untuk penanggulangan stunting (antara lain adalah Kabupaten Jember, Kabupaten Nganjuk dan Kab Lamongan), dan di tahun 2019 bertambah 1 kabupaten, yaitu Kabupaten Kediri ${ }^{4}$. Meskipun data Riset Kesehatan Dasar tahun 2018 menunjukkan bahwa terjadi penurunan angka stunting dibandingkan pada tahun 2013, angka stunting di Jawa Timur masih berada pada angka lebih dari $30 \%{ }^{5}$. Pemerintahan Provinsi Jawa Timur merespon situasi diatas dengan adanya berbagai kebijakan dan program nyata untuk mencegah dan menanggulangi permasalahan stunting yang ada. Hal tersebut dapat terlihat antara lain dengan adanya komitmen dari Wakil Gubenur Jawa Timur dan Dinas Kesehatan Provinsi Jawa Timur menerbitkan buku pedoman penggunaan dana desa untuk prioritas kesehatan. Buku itu nantinya akan dibagikan untuk kepala desa di Jatim sebagai acuan penggunaan dana desa dalam bidang kesehatan. Salah satu poinnya adalah menggunakan paling banyak sepuluh persen dana desa sebagai upaya penurunan stunting ${ }^{6}$.

Upaya penurunan angka stunting dilakukan melalui 2 pendekatan, yaitu pendekatan gizi spesifik untuk mengatasi penyebab langsung dari stunting dan pendekatan gizi sensitif untuk mengatasi penyebab tidak langsung ${ }^{1}$. Kedua pendekatan tersebut jika dilakukan secara bersamaan merupakan upaya penurunan angka stunting yang terintegrasi. Bappenas meluncurkan panduan intervensi penurunan stunting terintegrasi pemerintah kabupaten/kota dalam menurunkan kejadian stunting. Berdasarkan panduan tersebut terdapat 8 indikator utama, antara lain adalah : persentase bayi dengan Berat Bayi Lahir Rendah (BBLR); prevalensi kekurangan gizi (underweight) pada anak balita; prevalensi anak balita kurus (wasting) dan persentase bayi usia kurang dari 6 bulan yang mendapat ASI eksklusif ${ }^{7}$.

Dari beberapa indikator diatas, berdasarkan hasil Riskesdas 2018, Provinsi Jawa Timur angkanya adalah sebagai berikut: persentase BBLR sebesar 6,5\%; prevalensi underweight pada balita sebesar $15 \%$; prevalensi wasting pada balita sebesar $8 \%$ dan cakupan ASI eksklusif sebesar $40 \%$. Profil Kesehatan Provinsi Jawa Timur 2018, menujukkan angka yang berbeda dari Riskesdas 2018 untuk indikator yang sama, berikut adalah angkanya: persentase BBLR sebesar 3,7\%; serta cakupan ASI eksklusif sebesar 76,83\%, untuk indikator prevalensi underweight dan wasting pada balita tidak ditemukan angkanya, namun demikian terdapat data bahwa angka Balita berat badan di bawah garis merah (BGM) adalah sebesar $0,77 \%{ }^{8}$.

Dari data diatas dapat dilihat bahwa Provinsi Jawa Timur memiliki pekerjaan rumah yang cukup banyak untuk menanggulangi permasalahan stunting. Penanggulangan pada aspek spesifik dan sensitive di Jawa Timur perlu lebih ditingkatkan lagi dan melibatkan banyak sector serta yang terpenting adalah meningkatkan komitmen dari pimpinan wilayah mulai dari tingkat yang paling rendah sampai dengan tingkat yang paling tinggi ${ }^{7}$.

Provinsi Jawa Timur sebagai salah satu provinsi yang memiliki banyak prestasi di tingkat nasional maupun internasional, perlu lebih sistematis dan tertata dalam merumuskan dan mengoperasionalisasikan upaya pencegahan dan penanggulangan permasalahan stunting. Balita di Provinsi Jawa Timur mempunyai hak dan kesempatan yang sama untuk tumbuh norma, sehat dan kelak dapat berkontribusi untuk Provinsi Jawa Timur pada khususnya dan Indonesia pada umumnya.

Tujuan dari penelitian ini adalah untuk menentukan determinan balita stunting di Provinsi Jawa Timur. Variabel yang dilihat dalam riset ini mengacu kepada konsep dasar dari Unicef, bahwa ada faktor sosial budaya yang berperan dalam terjadinya permasalahan stunting. Tujuan ini penting bagi pengambil kebijakan untuk mengevaluasi pencapaian program gizi masyarakat, sekaligus menyediakan panduan untuk menentukan sasaran kebijakan program penganggulangan stunting yang tepat dan spesifik.

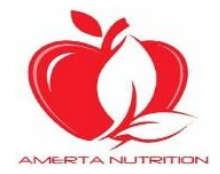

(C)2020. Laksono dan Megatsari. Open access under CC BY - SA license.

Received: 23-12-2019, Accepted: 10-02-2020, Published online: 18-06-2020.

doi: 10.20473/amnt. v4i2.2020.109-115 . Joinly Published by IAGIKMI \& Universitas Airlangga 


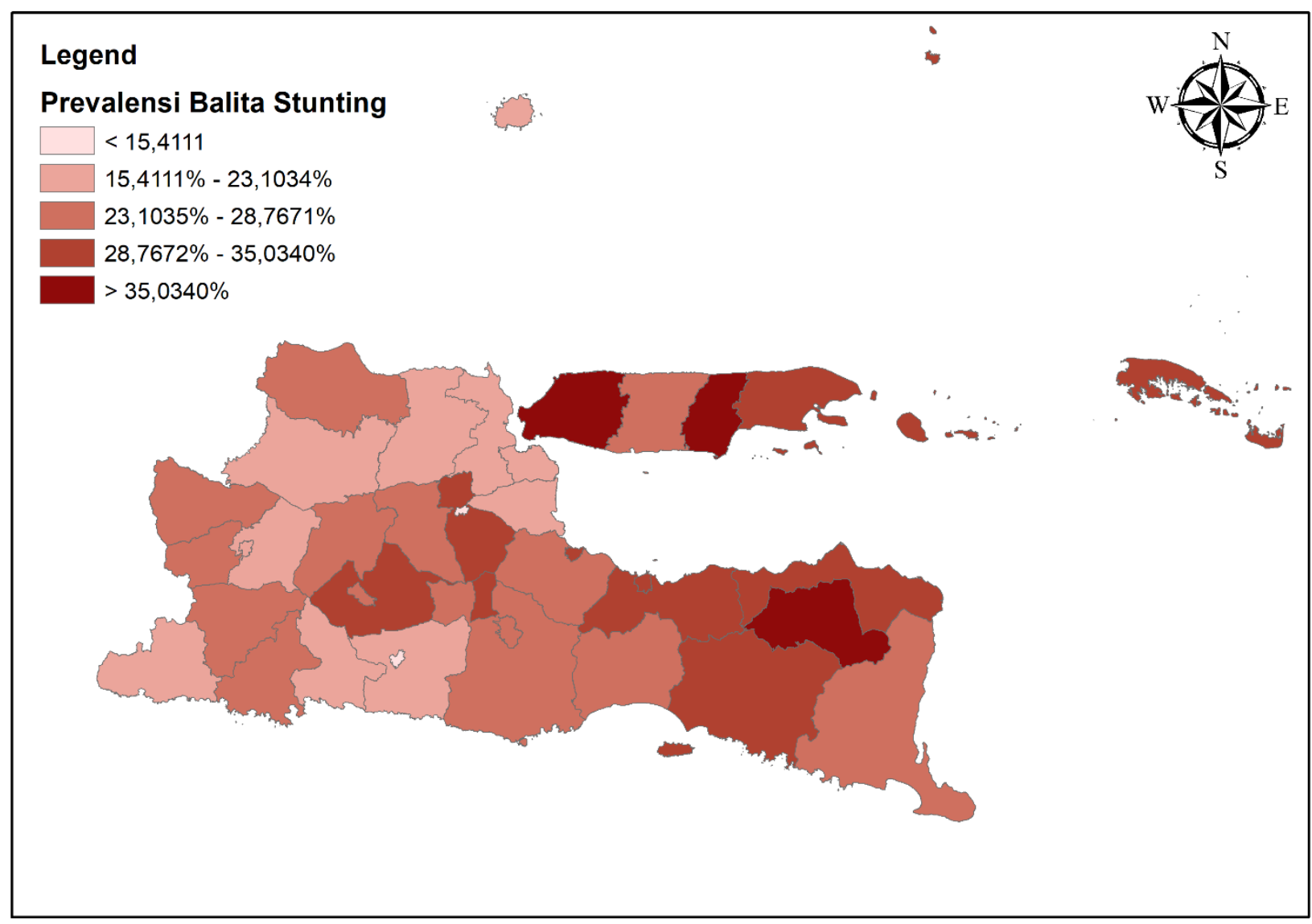

Gambar 1. Prevalensi balita stunting di Jawa Timur tahun 2017, Sumber: Survei PSG tahun 2017

Sedang variabel dependen terdiri dari tempat

\section{METODE}

Analisis dalam studi ini memanfaatkan data sekunder dari survei Pemantauan Status Gizi (PSG) tahun 2017. PSG 2017 merupakan survei skala nasional yang dilaksanakan oleh Kementerian Kesehatan RI. Pengambilan sampel dalam PSG 2017 dilakukan dengan metode multistage cluster random sampling ${ }^{9}$. Dengan unit analisis balita berusia 0-59, maka besar sampel yang dapat dianalisis sebesar 10.814 balita. PSG 2017 telah lolos uji etik melalui komite etika nasional (No. LB.02.01/2/KE.244/2017).

Variabel dependen sebagai variabel utama dalam studi ini adalah status stunting balita. Stunting adalah indikator status gizi yang dinilai berdasarkan tinggi badan per umur. Pengukuran dilakukan dengan cara ditimbang menggunakan timbangan digital dengan ketelitian 2 angka di belakang koma. Indikator ditentukan berdasarkan skor-z, yang merupakan standar deviasi dari tinggi normal sesuai dengan standar pertumbuhan WHO. Batas untuk kategori status gizi anak di bawah 5 tahun menurut indeks tinggi badan WHO per usia adalah sebagai berikut ${ }^{9}$ :

- Stunting: $<-2.0 \mathrm{SD}$

- Normal : $\geq-2$ SD tinggal (desa/kota), umur balita, jenis kelamin balita, umur ibu balita, status perkawinan ibu, tingkat pendidikan, ibu dan status pekerjaan ibu.

Pada tahap awal dilakukan uji kolinieritas antar variabel. Selanjutnya seleksi variabel dilakukan dengan dua uji yang berbeda, untuk variabel dikotomi dilakukan dengan Chi-square, sedang variabel kontinyu dengan Uji-t. Pada tahap akhir dilakukan uji Regresi Logistik Biner untuk menentukan apakah variabel independen yang diuji termasuk sebagai determinan balita stunting atau tidak.

\section{HASIL DAN PEMBAHASAN}

Sebelum menjalankan uji regresi logistik biner, peneliti melakukan uji co-linieritas. Tabel 1 menunjukkan hasil uji co-linieritas yang menunjukkan bahwa tidak ada co-linieritas antara variabel dependen dan variabel independen.

Tabel 1 memperlihatkan bahwa nilai tolerance seluruh variabel independen lebih besar dari 0.10 . Sementara nilai VIF untuk seluruh variabel kurang dari 10.00. Maka berpegangan pada dasar pengambilan keputusan dalam uji multikolonieritas dapat disimpulkan bahwa tidak terjadi gejala multikolinearitas dalam model regresi. 
Tabel 1. Hasil Uji Kolinieritas

\begin{tabular}{lcc}
\hline \multirow{2}{*}{ Variabel } & \multicolumn{2}{c}{ Statistik } \\
\cline { 2 - 3 } & Tolerance & VIF \\
\hline $\begin{array}{l}\text { Tempat Tinggal } \\
\text { (perkotaan/perdesaan) }\end{array}$ & 0,941 & 1,062 \\
Umur Balita (dalam bulan) & 0,988 & 1,012 \\
Umur Ibu (dalam tahun) & 0,948 & 1,055 \\
Status Perkawinan Ibu & 0,990 & 1,010 \\
Pendidikan Ibu & 0,905 & 1,105 \\
Status Bekerja Ibu & 0,957 & 1,045 \\
\hline
\end{tabular}

*Variabel Dependen: Status Gizi Balita

Tabel 2 adalah deskripsi statistik dari seluruh variabel yang menjadi objek analisis dalam penelitian ini. Dari tabel 2 juga menunjukkan bahwa balita di Jawa Timur dominan tinggal di perdesaan pada semua kategori status gizi. Ada perbedaan yang signifikan antara status gizi balita kategori stunting berdasarkan kategori daerah perkotaanpedesaan.

Tabel 2 juga menggambarkan bahwa rata-rata balita stunting memiliki umur lebih tua daripada balita yang memiliki status gizi normal. Sedang rata-rata umur ibu balita stunting sedikit lebih muda dibanding ibu balita yang memiliki status gizi normal. Ada perbedaan yang signifikan antara status gizi balita kategori stunting berdasarkan kategori umur balita maupun umur ibu balita.

Selain itu, tabel 2 mendeskripsikan bahwa balita dengan status gizi stunting maupun normal didominasi dengan ibu yang memiliki status pernikahan menikah. Tabel 2 juga menginformasikan bahwa balita stunting dominan memiliki ibu berpendidikan SD ke bawah. Tidak ada perbedaan yang signifikan antara status gizi balita kategori stunting berdasarkan kategori status perkawinan ibu. Sedang berdasarkan kategori tingkat pendidikan ibu menunjukkan perbedaan yang signifikan.

Tabel 2. Statistik Deskriptif Status Gizi Balita dan Variabel yang Berkaitan

\begin{tabular}{|c|c|c|c|c|}
\hline \multirow{2}{*}{ Variabel } & \multicolumn{2}{|c|}{ Status Gizi Balita } & \multirow{2}{*}{ Semua } & \multirow{2}{*}{$P$} \\
\hline & Normal & Stunting & & \\
\hline Tempat tinggal & & & & $*<0,001$ \\
\hline - Perkotaan & $2.325(29,3 \%)$ & $732(25,4 \%)$ & $3.057(28,3 \%)$ & \\
\hline - Perdesaan (Ref.) & $5.602(70,7 \%)$ & $2.155(74,6 \%)$ & $7.757(71,7 \%)$ & \\
\hline Umur balita (dalam bulan, rata-rata) & $7927(22,77)$ & $2887(30,46)$ & $10814(24,82)$ & $*<0,001$ \\
\hline Umur ibu (dalam tahun, rata-rata) & $7927(30,76)$ & $2887(30,74)$ & $10814(30,75)$ & $*<0,001$ \\
\hline Status perkawinan ibu & & & & 0,078 \\
\hline - Belum menikah & $20(0,3 \%)$ & $6(0,2 \%)$ & $26(0,2 \%)$ & \\
\hline - Menikah & $7.827(98,7 \%)$ & $2.837(98,3 \%)$ & $10.664(98,6 \%)$ & \\
\hline - Janda (Ref.) & $80(1,0 \%)$ & $44(1,5 \%)$ & $124(1,1 \%)$ & \\
\hline Tingkat pendidikan ibu & & & & $*<0,001$ \\
\hline - SD ke bawah & $1.878(23,7 \%)$ & $939(32,5 \%)$ & $2.817(26,0 \%)$ & \\
\hline - SLTP & $2.075(26,2 \%)$ & $835(28,9 \%)$ & $2.910(26,9 \%)$ & \\
\hline - SLTA & $3.157(39,8 \%)$ & $928(32,1 \%)$ & $4.085(37,8 \%)$ & \\
\hline • PT (Ref.) & $817(10,3 \%)$ & $185(6,4 \%)$ & $1.002(9,3 \%)$ & \\
\hline Status bekerja ini & & & & 0,284 \\
\hline - Tidak bekerja & $5.176(65,3 \%)$ & $1917(66,4 \%)$ & 7.093 (65,6\%) & \\
\hline - Bekerja (Ref) & $2.751(34,7 \%)$ & $970(33,6 \%)$ & $3.721(34,4 \%)$ & \\
\hline
\end{tabular}

Catatan: Chi-Square digunakan untuk menguji variabel dikotomi, dan uji-t untuk menguji variabel kontinyu. *Signifikan pada tingkat $95 \%$.

Tabel 2 memperlihatkan bahwa balita dengan status gizi stunting maupun normal didominasi dengan ibu yang memiliki status tidak bekerja. Tidak ada perbedaan yang signifikan antara status gizi balita kategori stunting berdasarkan kategori status bekerja.

Berdasarkan informasi pada tabel 2, maka variabel yang akan diuji dengan regresi logistik biner ada 4 (empat) variabel. Keempat variabel tersebut adalah tempat tinggal, umur balita, umur ibu balita, dan tingkat pendidikan ibu balita.

Tabel 3 menunjukkan hasil uji regresi logistik biner untuk menentukan determinan kejadian balita stunting di Jawa Timur. Dalam uji regresi logistik biner ini, status gizi balita kategori "normal" digunakan sebagai referensi.
Tabel 3 menunjukkan bahwa balita yang tinggal di daerah perkotaan 0,855 kali lebih memiliki risiko stunting dibandingkan dengan balita yang tinggal di daerah pedesaan (OR 0,885; 95\% Cl 0,798-0,980). Artinya balita yang tinggal di daerah perdesaan memiliki risiko stunting yang lebih besar. Tabel 3 memperlihatkan bahwa umur balita maupun umur ibu balita terbukti signifikan sebagai determinan kejadian balita stunting di Jawa Timur.

Hasil analisis menunjukkan bahwa balita yang tinggal di daerah perdesaan memiliki risiko stunting yang lebih besar. Temuan ini sejalan dengan hasil penelitian di wilayah Tanzania yang menemukan bahwa balita yang tinggal di wilayah perkotaan memiliki risiko lebih rendah untuk stunting. Balita di perkotaan Tanzania memiliki risiko 0,56 kali untuk stunting dibanding balita di wilayah 
perdesaan. Penelitian ini menemukan faktor risiko lain di Tanzania yang meliputi kemiskinan, tidak berpendidikan, dan rumah tangga yang dikepalai oleh seorang wanita ${ }^{10}$. Penelitian di Bangladesh juga menyimpulkan hasil yang sejalan, balita yang tinggal di wilayah perkotaan memiliki risiko 1,31 kali dibanding balita yang tinggal di wilayah perdesaan Bangladesh untuk menjadi stunting. Temuan yang berbeda ditemukan dalam sebuah penelitian di Pakistan. Balita yang tinggal di perdesaan Pakistan justru memiliki risiko lebih rendah untuk stunting. Balita di perdesaan Pakistan memiliki risiko 0,67 kali dibanding balita di perkotaan untuk menjadi stunting ${ }^{11}$.

Tabel 3. Uji Determinan Kejadian Balita Stunting

\begin{tabular}{lccc} 
& Variabel & \multicolumn{2}{c}{ Stunting } \\
\cline { 2 - 4 } & Odd Ratio & Batas Bawah & Batas Atas \\
\hline Tempat Tinggal: Perkotaan & $* 0,885$ & 0,798 & 0,980 \\
Umur Balita & $* * * 1,031$ & 1,028 & 1,034 \\
Umur Ibu & $* * * 0,987$ & 0,981 & 0,993 \\
Pendidikan Ibu: SD ke bawah & $* * * 2,206$ & 1,835 & 2,651 \\
Pendidikan Ibu: SLTP & $* * * 1,676$ & 1,395 & 2,015 \\
Pendidikan Ibu: SLTA & $* * 1,266$ & 1,058 & 1,514 \\
\hline
\end{tabular}

Catatan: Referensi “normal”; Confidence interval OR 95\%; *p<0,05, **p<0,01, ***p<0,001.

Di Indonesia, disparitas antara wilayah perkotaan dengan perdesaan bukanlah hal baru. Pembangunan di wilayah perkotaan terlihat lebih atraktif dibanding wilayah perdesaan. Kesenjangan tidak hanya berlangsung dalam hal pembangunan secara umum, tetapi juga termasuk aksesibilitas dalam hal pelayanan kesehatan yang telah ditemukan dalam analisis beberapa hasil penelitian ${ }^{12,13}$.

Hasil analisis menunjukkan bahwa umur balita merupakan determinan kejadian stunting di Provinsi Jawa Timur. Hasil analisis yang sama di level nasional juga ditemukan dalam penelitian di Indonesia lainnya ${ }^{14,15}$. Sementara studi di beberapa negara juga menemukan hasil yang sejalan, yaitu di Ethiopia ${ }^{16,17,18}$, Ghana ${ }^{19}$, Uganda $^{20}$, Tanzania ${ }^{10}$, dan India ${ }^{21}$.

Hasil penelitian menunjukkan bahwa selain umur balita, umur ibu balita juga merupakan determinan kejadian stunting di Provinsi Jawa Timur. Temuan yang sejalan juga dihasilkan dalam beberapa penelitian di Tanzania ${ }^{10,22}$, Rwanda ${ }^{23}$, dan India ${ }^{24}$. Secara spesifik penelitian di India juga menjelaskan bahwa umur ibu balita ketika pertama kali menikah menikah dan umur ibu ketika melahirkan merupakan determinan kejadian stunting tersebut ${ }^{24}$.

Tabel 3 menginformasikan bahwa balita yang memiliki ibu dengan pendidikan SD ke bawah 2,206 kali lebih memiliki risiko stunting dibandingkan dengan balita yang memiliki ibu dengan pendidikan perguruan tinggi (OR 2,206; $95 \% \mathrm{Cl} 1,835-12,651)$. Balita yang memiliki ibu dengan pendidikan SLTP 1,676 kali lebih memiliki risiko stunting dibandingkan dengan balita yang memiliki ibu dengan pendidikan perguruan tinggi (OR 1,676;95\% Cl $1,395-2,015)$. balita yang memiliki ibu dengan pendidikan SLTA 1,266 kali lebih memiliki risiko stunting dibandingkan dengan balita yang memiliki ibu dengan pendidikan perguruan tinggi (OR 1,266; 95\% Cl 1,058-1,514). Berdasarkan informasi tersebut dapat diartikan bahwa semakin rendah tingkat pendidikan ibu balita, maka semakin memiliki risiko untuk stunting.

Analisis dalam penelitian ini menemukan bahwa semakin rendah tingkat pendidikan ibu balita, maka balita semakin memiliki risiko untuk stunting. Hasil temuan ini sejalan dengan beberapa penelitian lain di Indonesia $15,25,26$. Penelitian yang mengambil topik kajian yang sama di India ${ }^{27}$, Ethiopia ${ }^{16,28}$, Tanzania ${ }^{10}$, Uganda ${ }^{20}$, Vietnam ${ }^{29}$, dan Paraguay ${ }^{30}$ juga menemukan hasil analisis yang sejalan, tingkat pendidikan ibu merupakan determinan kejadian stunting pada balita, selain tingkat sosial ekonomi.

Studi lain pada konteks di Indonesia menemukan bahwa tingkat sosial ekonomi turut berpengaruh terhadap kejadian stunting pada balita 15,26,31. Dapat dijelaskan bahwa semakin tinggi tingkat sosial ekonomi maka semakin banyak jumlah dan bervariasi ketersediaan jenis makanan yang disediakan pada tingkat rumah tangga ${ }^{32}$. Di sisi lain, tingkat sosial ekonomi selalu memiliki hubungan yang positif dengan tingkat pendidikan. Mereka yang miskin cenderung ditemukan memiliki pendidikan rendah 33,34

Kekuatan dari penelitian adalah berhasil membuktikan bahwa stunting disebabkan faktor multidimensional yang sangat terkait dengan lingkungan tempat dia tinggal. Penelitian ini memiliki keterbatasan khas desain penelitian kuantitatif yang bersifat superfisial, hanya melihat fenomena di permukaan. Masih diperlukan penelitian kualitatif lebih lanjut tentang bagaimana tingkat pendidikan ibu balita dapat menjadi salah satu faktor yang berpengaruh terhadap kejadian stunting pada balita di Jawa Timur.

\section{KESIMPULAN}

Berdasarkan hasil penelitian dapat disimpulkan bahwa ada 4 (empat) variabel yang terbukti signifikan 
sebagai determinan kejadian stunting di Provinsi Jawa Timur. Keempat variabel itu adalah tempat tinggal (perkotaan/perdesaan), umur balita (dalam bulan), umur ibu balita (dalam tahun), dan tingkat pendidikan ibu balita. Berdasarkan kesimpulan maka peneliti merekomendasikan pada pemerintah daerah di Provinsi Jawa Timur untuk memfokuskan sasaran intervensi pada ibu balita yang memiliki tingkat pendidikan rendah. Upaya peningkatan pengetahuan pada kategori sasaran ini, terutama di wilayah perdesaan, tentang bagaimana meningkatkan status gizi balita penting dilakukan untuk mengakselerasi upaya penanggulangan balita stunting di Jawa Timur.

\section{ACKNOWLEDGEMENT}

Penulis mengucapkan terimakasih kepada mahasiswa yang membantu dalam pengumpulan data dan teman dosen atas masukan, pendapat maupun saran dalam perancangan dan penyelesaian penulisan artikel ini.

\section{REFERENSI}

1. Kemenkes. Buletin Stunting. Kementeri. Kesehat. Republik Indones. 301, 1163-1178 (2018).

2. de Onis, M. \& Branca, F. Childhood stunting: A global perspective. Matern. Child Nutr. 12, 12-26 (2016).

3. Victora, C. G. et al. Maternal and child undernutrition: consequences for adult health and human capital. Lancet 371, 340-357 (2008).

4. Tim Nasional Percepatan Penanggulangan Kemiskinan. Daftar Wilayah Prioritas Tahap 2/ 2018 ( 160 Kabupaten / Kota Prioritas ). (2018).

5. Kementerian Kesehatan RI, B. P. dan P. RISET KESEHATAN DASAR. (2018).

6. Radar Surabaya, J. P. Wagub Emil: 10 Persen Dana Desa untuk Turunkan Stunting. (2019).

7. Kementerian PPN/ Bappenas. PEDOMAN PELAKSANAAN INTERVENSI PENURUNAN STUNTING TERINTEGRASI DI KABUPATEN/ KOTA. Rencana Aksi Nasional dalam Rangka Penurunan Stunting: Rembuk Stunting 1-51 (2018).

8. Provinsi Jawa Timur, D. K. Profil Kesehatan Jawa Timur 2018. 100 (2019).

9. Directorate of Community Nutrition of The Ministry of Health of The Republic of Indonesia. the 2017 Indonesia Nutritional Status Monitoring (Pemantauan Status Gizi 2017). (2017).

10. Sunguya, B. F., Zhu, S., Mpembeni, R. \& Huang, J. Trends in prevalence and determinants of stunting in Tanzania: An analysis of Tanzania demographic health surveys (1991-2016). Nutr. J. 18, Article number 85 (2019).

11. Khan, S., Zaheer, S. \& Safdar, N. F. Determinants of stunting, underweight and wasting among children $<5$ years of age: Evidence from 20122013 Pakistan demographic and health survey.
BMC Public Health 19, Article number 358 (2019).

12. Laksono, A. D., Wulandari, R. D. \& Soedirham, O. Urban and Rural Disparities in Hospital Utilization among Indonesian Adults. Iran. J. Public Health 48, 247-255 (2019).

13. Wulandari, R. D. \& Laksono, A. D. Urban-Rural Disparity: The Utilization of Primary Health Care Center Among Elderly in East Java, Indonesia. J. Adm. Kesehat. Indones. 7, 147-154 (2019).

14. Titaley, C. R., Ariawan, I., Hapsari, D., Muasyaroh, A. \& Dibley, M. J. Determinants of the stunting of children under two years old in Indonesia: A multilevel analysis of the 2013 Indonesia basic health survey. Nutrients 11, Article number 1106 (2019).

15. Laksono, A. D., Ibad, M., Mursita, A., Kusrini, I. \& Wulandari, R. D. Characteristics of mother as predictors of stunting in toddler. Pakistan J. Nutr. 18, 1101-1106 (2019).

16. Tekile, A. K., Woya, A. A. \& Basha, G. W. Prevalence of malnutrition and associated factors among under-five children in Ethiopia: Evidence from the 2016 Ethiopia Demographic and Health Survey. BMC Res. Notes 12, Article number 391 (2019).

17. Fantay Gebru, K., Mekonnen Haileselassie, W., Haftom Temesgen, A., Oumer Seid, A. \& Afework Mulugeta, B. Determinants of stunting among under-five children in Ethiopia: A multilevel mixed-effects analysis of 2016 Ethiopian demographic and health survey data. BMC Pediatr. 19, Article number 176 (2019).

18. Takele, K., Zewotir, T. \& Ndanguza, D. Understanding correlates of child stunting in Ethiopia using generalized linear mixed models. BMC Public Health 19, Article number 626 (2019).

19. Boah, M., Azupogo, F., Amporfro, D. A. \& Abada, L. A. The epidemiology of undernutrition and its determinants in children under five years in Ghana. PLoS One 14, Article number e0219665 (2019).

20. Yang, Y. Y. et al. Trends and determinants of stunting among under-5s: Evidence from the 1995, 2001, 2006 and 2011 Uganda Demographic and Health Surveys. Public Health Nutr. 21, 29152928 (2018).

21. Sinha, R., Dua, R., Bijalwan, V., Rohatgi, S. \& Kumar, P. Determinants of stunting, wasting, and underweight in five high-burden pockets of four Indian states. Indian J. Community Med. 43, 279283 (2018).

22. Muhimbula, H., Kinabo, J. \& O'Sullivan, A. Determinants of infant nutrition status in rural farming households before and after harvest. Matern. Child Nutr. 15, Article number e12811 (2019).

23. Uwiringiyimana, V., Veldkamp, A. \& Amer, S. Stunting spatial pattern in rwanda: An 
examination of the demographic, socio-economic and environmental determinants. Geospat. Health 14, 329-339 (2019).

24. Sethi, V. et al. Severity and determinants of stunting in children under age 2 years in Odisha (India): a tribal v/s non-tribal analysis. Asian Ethn. 19, 489-508 (2018).

25. Sasongko, E. P. S., Ariyanto, E. F., Indraswari, N., Rachmi, C. N. \& Alisjahbana, A. Determinants of adolescent shortness in Tanjungsari, West Java, Indonesia. Asia Pac. J. Clin. Nutr. 28, S43-S50 (2019).

26. Beal, T., Tumilowicz, A., Sutrisna, A., Izwardy, D. \& Neufeld, L. M. A review of child stunting determinants in Indonesia. Matern. Child Nutr. 18, (2018).

27. Pillai, V. K. \& Maleku, A. Women's education and child stunting reduction in India. J. Sociol. Soc. Welf. 4, 111-130 (2019).

28. Dessie, Z. B., Fentie, M., Abebe, Z., Ayele, T. A. \& Muchie, K. F. Maternal characteristics and nutritional status among 6-59 months of children in Ethiopia: Further analysis of demographic and health survey. BMC Pediatr. 19, Article number 83 (2019).
29. Beal, T. et al. Child stunting is associated with child, maternal, and environmental factors in Vietnam. Matern. Child Nutr. 15, Article number e12826 (2019).

30. Ervin, P. A. \& Bubak, V. Closing the rural-urban gap in child malnutrition: Evidence from Paraguay, 1997-2012. Econ. Hum. Biol. 32, 1-10 (2019).

31. Krisnana, I., Azizah, R., Kusumaningrum, T. \& Has, E. M. M. Feeding patterns of children with stunting based on WHO (world health organization) determinant factors of behaviours approach. Indian J. Public Heal. Res. Dev. 10, 2756-2761 (2019).

32. Dranesia, A., Wanda, D. \& Hayati, H. Pressure to eat is the most determinant factor of stunting in children under 5 years of age in Kerinci region, Indonesia. Enferm. Clin. In press, (2019).

33. Chaturvedi, B. K. Poverty and development: global problems from an Indian perspective. J. Glob. Ethics 15, 55-66 (2019).

34. Sano, Y., Routh, B. \& Lanigan, J. Food parenting practices in rural poverty context. Appetite 135, 115-122 (2019). 